\title{
Makaleler
}

\section{Özel Sektör Dengesinin Hükümet Bütẹsi Üzerindeki Etkisi: Ampirik Bir İnceleme}

Taner TURAN 1 - Orhan Emre ELMA ${ }^{2}$

Makale Gönderim Tarihi: 1 1.05.2015

Makale Kabul Tarihi: 30.12.2015

\section{Öz}

Bu çalıșmanın amacı, Türkiye'de özel sektör dengesinin hükümet bütçesi üzerindeki etkisini büyüme oranı, finans hesabı dengesi ve hanehalkı tüketim harcamalarını kullanarak incelemektir. Bu kapsamda ARDL yaklașımı kullanılmıștır. Bulgular özel sektör dengesinin, hükümet bütçesi dengesi üzerinde anlamlı bir etkide bulunmadığını göstermektedir. Finans hesabı dengesinin, hükümet bütçe dengesini uzun ve kısa dönemde önemli biçimde etkileyen tek değișken olduğu sonucuna ulașılmaktadır.

Anahtar Kelimeler: Özel Sektör Dengesi, Hükümet Bütçe Dengesi, Finans Hesabı Dengesi, Özel Sektör Davranıșının Ełkisi.

Jel Sınıflaması: E62, F00, H60

Assoc. Prof., Gebze Technical University, Business Faculty, Department of Economics, tturan@gtu.edu.tr

2 Res. Assist., Adana Science and Technology University, Business Faculty, International Trade and Finance Department, oeelma@adanabtu.edu.tr 


\section{The Effect Of Private Sector Balance On Government Budget: An Empirical Examination}

\section{ABSTRACT}

This paper aims to examine the effect of private sector balance (PSB) on government budget balance (BD) in Turkey by using growth rate (GE), financial account balance (FA), and household consumption expenditures $(\mathrm{CH})$. In this context, ARDL approach is employed. Findings suggest that PSB does not have a significant effect on $B D$. FA has been found to be the only variable which has a significant effect on BD in both the long and short run.

Keywords: Private Sector Balance, Government Budget Balance, Financial Account Balance, Impact of Private Sector Behaviour.

\section{INTRODUCTION}

The relationship between the private and public balance has become more important and relevant as the trade and financial/ capital liberalization significantly increase around the world since especially 1980s. As a result, this relationship has drawn more attention from researchers over time.

Although there are some exceptions, Turkey has had a substantial current account deficit for a long time. Seasonally adjusted current account deficit has been constantly above 4,5 $\%$ of GDP since 2010:Q1. As discussed by Hakkio (1995), high current account deficits can lead to some important problems in economic activity. For instance, high current account deficits can make an economy more fragile to external risks and shocks. However, in an emerging economy like Turkey, a current account deficit enables to make more investment than its domestic saving could afford. So a current account deficit may not be a bad thing per se, at least until some level. On the contrary to the current account deficits, in Turkey, the central government budget deficit has declined substantially after 2003 , to a large extent, because of IMF supported program, high growth rates, relatively strict fiscal policy and favorable international financial conditions. 
Seasonally adjusted budget deficit has been less than $3 \%$ after 2011:Q1. On the other hand, the private sector balance displays a different pattern over time. The private sector balance has been negative for a long time. In general, the private sector balance has deteriorated when the government budget balance has improved and current account deficit has increased after around 2004. This actually arises from the fact that how we construct the private sector balance, following Ciumas et al. (2012).

Although our main objective is to examine the effect of private sector balance (PSB) on the government budget balance (BD), we control some other variables, namely the financial account (FA), growth rate of GDP (GE), and household consumption expenditures (CH). We use Turkish quarterly data from 1998:1 to 2014:1 and ARDL approach to cointegration. Once we find that there is a cointegrating relationship, we estimate the long and short run coefficients. We also perform short run Granger causality tests.

The remainder of the paper is organised as follows: We briefly summarize the literature in section 2 , explain the data and report unit root tests in section 3, visually examine the variables in section 4, present and discuss the empirical results in section 5 and conclude in section 6 .

\section{Literature Review}

Ciumas et al. (2012), for 10 European countries, find a strong relationship between private sector behavior and budget balance. They claim that some countries implement a countercyclical policy while the others don't.

Unlike our study, the literature largely examine the twin deficit hypothesis and Ricardian equivalence hypothesis, the latter developed by Barro (1974, 1989). On the one hand Keynesian model predicts a positive relation between the current account and budget deficits. It is expected that causality goes from the budget deficit to the current account or trade deficit. But Marinheiro (2008) discusses why the causality may go from the current account deficit to budget deficit under some conditions. On the other hand Ricardian equivalence approach doesn't predict a causal 
relationship between the current account and budget deficit. A decline in public saving will lead to an equal rise in the private saving, implying no change in the total saving.

There is a very large literature, such as Khalid and Guan (1999), Salvatore (2006), Marinheiro (2008), Merza et al. (2012), Hatemi and Shukur (2002), Xie and Chen (2014) examining the relationship between the current account or trade deficit and budget deficit. ${ }^{3}$ As pointed out in a recent article by Kumhof and Laxton (2013) empirical findings are not robust on that issue. Acaravci and Ozturk (2008), Ümit and Yıldırım (2008), Gursoy and Ceylan (2011), and Erdoğan and Yıldırım (2014) support the twin deficit hypothesis while Kuștepeli (2001), Aksu and Bașar (2009), Kılavuz and Dumrul (2012) don't find a significant evidence for the twin deficit hypothesis in the case of Turkey. Similarly, Kıran (2011) concludes that there is a little evidence for the twin deficit hypothesis for Turkey. Varol lyidoğan and Erkam (2013) find that the causality goes from the current account deficit to budget deficit. In a nonlinear framework Çatık et al. (2015) report that the twin deficit hypothesis is supported in only upper regime but not in lower regime. However Akbass et al. (2014) conclude that the triple deficit hypothesis is valid for Turkey.

Bahmani-Oskooee and Payesteh (1994) examine the relationship between the budget balance and capital flows for the US by using time series techniques. Murthy and Phillips (1996) present some evidence for a long run relationship between budget deficit and capital inflows. Turan (2015a) also concludes that there is a bi-directional causality between the government budget and financial account balance in Turkey by using annual data over the period 1975-2014.

In a different strand of the literature, some studies, such as Fry et al. (1995), Wong and Carranza (1999), Yan (2005), Turan $(2015 b)$ examine the relationship between the current and capital/financial accounts. Erden and Çağatay (2011) find

3 A good overview of this literature can be found in Xie and Chen (2014). 
a causal relationship running from the capital account to current account in Turkey. Tang (2014) examines the relationship among current account, financial account and fiscal deficit in the US.

Cyclical behavior of fiscal policy has been intensively examined, such as Lane (2003), Gali and Perotti (2003), Kaminsky et al. (2004), Alesina et al. (2008), Abdih et al. (2010). Many studies find that especially developing countries largely implement procyclical policies. Turan and Telatar (2013a) and Turan (2013b) present some evidence that the primary surplus is countercyclical in Turkey in general. Turan (2013c) suggests that total real government expenditure has a negative and significant correlation with GDP and also points out the the main concern of Turkish fiscal policy is to give a primary surplus not cyclical fluctuations for some time. Similarly Turan (2014) finds that the government expenditures excluding interest payments and transfer spending display some countercyclical patterns in the contractions.

\section{Data and Unit Root Tests}

We use quarterly data for Turkey over the period 1998Q12014Q1. Our GDP, current account, financial account and consumption expenditures of households data come from Central Bank of Turkey, while central government budget balance data obtained from Turkish Ministry of Finance. ${ }^{4}$ We use the current account, financial account and central government budget balance as a share of GDP, while household consumption expenditures are used as the change from the previous period. Since we work with quarterly data, all variables are seasonally adjusted.

Like Ciumas et al. (2012) we estimate the private sector balance by deducting the government budget balance from the current account balance. Actually this is based on a well-known and simple identity, states that current account balance $(C A B)$ is equal to the sum of the differences between private saving (SA) and investment (IN), and government revenue (TR) and spending (GS), which can be written as follows:

4 Central government budget refers to consolidated government budget before 2006. 


$$
C A B=(S A-I N)+(T R-G S)
$$

More details can be found in some other studies, for example Khalid and Guan (1999), and Aristovnik and Djuric (2010).

We use Augmented Dickey-Fuller (ADF), KPSS and ZivotAndrews tests to determine whether our variables are stationary or not and summarize the results in Table 1.

\section{Table 1. Unit root test results}

\begin{tabular}{|l|l|l|l|l|l|}
\hline & \multicolumn{2}{|c|}{ ADF } & \multicolumn{2}{c|}{ KPSS } & Zivot-Andrews \\
\hline Var. & Level & 1 st difference & Level & 1 st difference & Level \\
\hline BD & $-2.102202(1)$ & $-6.966805^{*}(3)$ & $0.617446^{* *}$ & 0.154640 & $-3.122803(4)$ \\
\hline PSB & $-2.280688(0)$ & $-10.47691^{*}(0)$ & $0.746713^{*}$ & 0.076275 & $-4.758041(0)$ \\
\hline GE & $-6.318655^{*}(0)$ & - & 0.076699 & - & $-6.729870 *(0)$ \\
\hline FA & $-4.290489^{*}(0)$ & - & $0.568604^{* *}$ & 0.092904 & $-5.611645^{*}(0)$ \\
\hline CH & $-1.238608(4)$ & $-8.898440^{*}(3)$ & $0.837842^{*}$ & 0.103059 & $-4.242319(4)$ \\
\hline
\end{tabular}

Notes: ${ }^{*},{ }^{* *},{ }^{* * *}$ show significance levels at 1,5 and $10 \%$ respectively. Lag numbers are based on Schwarz Information Criteria (SIC). Lag numbers shown in parenthesis. The unit root tests are performed by using models with intercept. For Zivot-Andrews test, we allow a structural break in both the intercept and slope.

Based on ADF test results, in level we reject unit roots for $G E$ and FA but fail to reject for BD, PSB and $\mathrm{CH}$. KPSS results suggest that the null hypothesis of stationarity for BD and FA at $5 \%$ level and also PSB and $\mathrm{CH}$ at $1 \%$ level is rejected but not for GE. In first difference, all variables don't have unit roots. We also perform an approach developed by Zivot and Andrews (1992) to take possible structural breaks into consideration. The results indicate that we reject unit roots in the case of GE and FA but not for other variables, confirming the results of ADF test.

\section{Graphical Analysis}

Before presenting and discussing our regression results, a look at the evolution of our variables would be helpful. The evolution of GB, PSB, FA, CH and GE can be seen at Figure 1. 
In general, except for some quarters, the government budget deficit is more than $5 \%$ until 2004:4. The budget balance is the lowest in 2001, in which a severe financial crisis took place in Turkey. It is important to note that there is a considerable improvement in the budget deficit after 2003. Although the effect of global financial crisis on the budget deficit is clear and visible, budget deficit is not high in recent periods. It seems that the policies implemented after 2001 crisis have been successful in reducing the budget deficit and making Turkish public finance stronger.

During the period examined, there are some sharp fluctuations in the growth rate of real GDP (GE). GE is positive but below $2 \%$ after 2011:Q3. This means that when compared with mid-2000s there is a decline in the growth rate in recent periods. Finally we can say that the massive earthquake in 1998, economic crisis in 2001 and global crisis in 2008 have a remarkable negative effect on the growth rate in Turkey.

Figure 1. GB, PSB, FA, $C H$ and $G E$

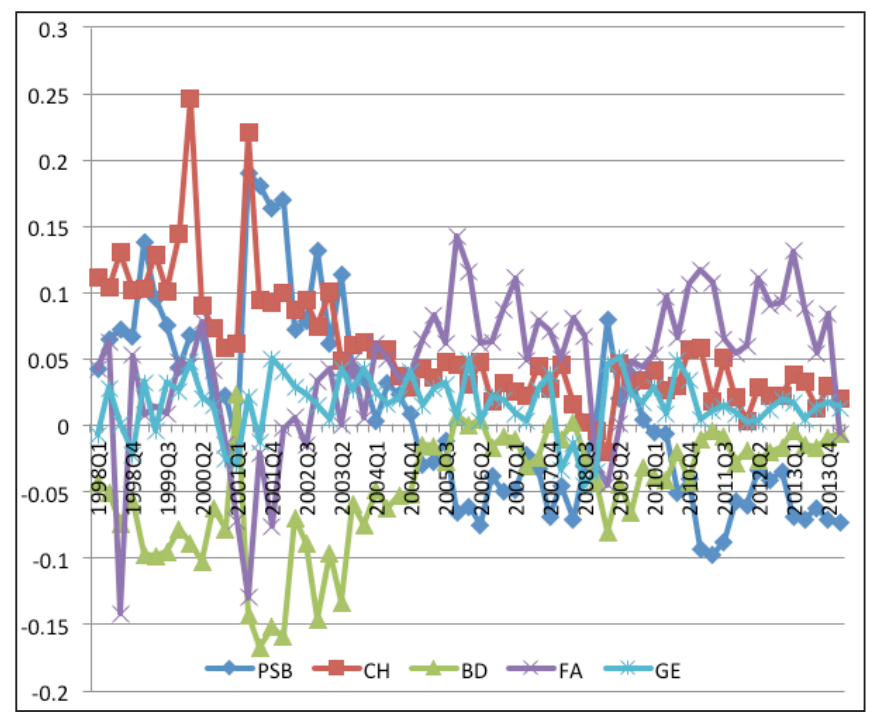

Source: Data taken from Central Bank of Turkey, and Turkish Ministry of Finance. 
As can be seen at Figure 1, actually there is a clear negative relation between the private sector balance and government budget balance. PSB is high when the government budget deficit is low and vice versa. We would like to point out that when the budget deficit is higher than the current account deficit, private sector has a surplus. After 2004 PSB is negative, while the BD is relatively low. This can also be interpreted as the private saving is less than the investment after 2004 in general. Obviously this can stem from both an increase in the investment or a decline in the private saving. Data from Turkish Ministry of Development clearly indicate that there is a sharp decline in the private saving after 2002. Private saving is $23,4 \%$ of GDP in 2002 while it is only $12,3 \%$ in 2010 . We think that, it is a good policy for Turkey to reduce the government deficits when the private sector deficit is high. The effects of banking crisis in Turkey can be seen in 2001 in which private sector balance reaches its highest values. Following the crisis, PSB deteriorates. Because of global financial crisis, the government budget deficit is high and current account deficit is low, while PSB is positive in 2008:Q4-2009:Q4.

Financial account balance is positive after 2002, except for a temporary decrease in 2008. It has seen its lowest values in 1998 and 2001. After that it has gradually increased and has been positive, except for 2008. In Turkey, since current account balance is negative, financal account balance is mostly positive during the period examined.

After some big changes in consumption expenditures, a more stable trend is observed after 2003. There is a significant change in 2008, because of the global crisis. As expected, the changes in consumption expenditures of households are relatively small in recent periods. This is in line with the evolution of the growth rate.

\section{Empirical Methodology and Results}

Ciumas et al. (2012) examine the relationship among the government balance, private sector balance, growth rate, financial account balance and household consumption expenditures by using OLS. We employ the same variables but take a different 
empirical approach. The long run relation between variables can be examined by means of standard cointegration tests, like Engle and Granger (1987), if the variables have the same order of integration. However, we have a mix of both $1(0)$ and $I(1)$ variables. Therefore a different approach, developed by Pesaran et al. (2001), can be used to examine whether a cointegrating relationship exists among the variables. If a cointegration is found, then the long run and short run coefficients can be estimated. We can write the conditional error correction model as follows :

$$
\begin{aligned}
\Delta B D_{t}= & \beta_{0}+\beta_{1} B D_{t-1}+\beta_{2} P S B_{t-1}+\beta_{3} G E_{t-1}+\beta_{4} F A_{t-1}+\beta_{5} C H_{t-1} \\
& +\sum_{i=1}^{m} \beta_{6} \Delta B D_{t-i}+\sum_{i=0}^{m} \beta_{7} \Delta P S B_{t-i} \\
& +\sum_{i=0}^{m} \beta_{8} \Delta G E_{t-i}+\sum_{i=0}^{m} \beta_{9} \Delta F A_{t-i}+\sum_{i=0}^{m} \beta_{10} \Delta C H_{t-i}+e_{t}(2)
\end{aligned}
$$

where $m$ is the optimal lag length determined by information criteria and $e_{t}$ is error term with zero mean and constant variance. While determining the optimal lag length, we also make sure that there is no serial correlation. Cointegration test is carried out by testing the joint significance of lagged variables, namely $\mathrm{H}_{0:} \beta_{1}=\beta_{2}=\beta_{3}$ $=\beta_{4}=\beta_{5}=0$. Estimated $\mathrm{F}$ statistic is compared to critical bounds provided by Pesaran et al. (2001). If $F$ statistic exceeds the upper bound then we conclude that a co-integrating relationship exists

We estimate Equation 2 to test whether there is a cointegration among the government budget balance, private sector balance, growth rate of GDP, financial account balance, household consumption expenditures. Bound testing result is reported in Table 2.

Table 2. Bound testing result

\begin{tabular}{|l|l|l|ll|}
\hline Dep. Variable & $\mathbf{m}$ & F-statistic & Critical values (lower bound-upper bound) \\
\hline $\mathrm{BD}$ & 0 & $6.330^{*}$ & $\frac{\text { F-stat }}{}$ & \\
& & & $\% 1$ & $(3.74-5.06)$ \\
& & & $\% 5$ & $(2.86-4.01)$ \\
& & & 10 & $(2.45-3.52)$ \\
\hline
\end{tabular}


Notes: $m$ stands for lag length which is based on Schwarz Criterion. F- statistic is compared to the critical values for $k=4$ in Pesaran et al. (2001, p.300). * shows the significance at the $1 \%$ level.

Since F statistic exceeds critical bounds at $1 \%$ significance level, we conclude that a cointegrating relation exists, and therefore we can estimate the long and short run coefficients.

Table 3. Long-Run coefficients

\begin{tabular}{|l|l|l|l|}
\hline \multicolumn{4}{|c|}{ ARDL $(1,0,0,1,4)$ (Dependent variable: BD) } \\
\hline Regressor & \multicolumn{1}{|c|}{ Coefficient } & \multicolumn{1}{|c|}{ Standard Error } & \multicolumn{1}{c|}{ t-ratio (prob) } \\
\hline PSB & -0.027361 & 0.092071 & $-0.29718(0.768)$ \\
\hline GE & -0.051289 & 0.14157 & $-0.36229(0.719)$ \\
\hline FA & -0.59387 & 0.081359 & $-7.2993(0.000)$ \\
\hline CH & -0.060066 & 0.10714 & $-0.56065(0.578)$ \\
\hline Constant & -0.041658 & 0.0080277 & $-5.1893(0.000)$ \\
\hline
\end{tabular}

Notes: Model selection is based on SBC.

The estimated long run coefficients are presented in Table 3 above. Our long run estimates suggest that the FA is the only variable which has a significant effect on $B D$. A negative long run relationship exists between $B D$ and $F A$, meaning an increase in $F A$ leads to a decrease in BD. This negative relationship, in general, is consistent with that of Ciumas et. al (2012) who also report a significant negative relationship between the government budget and financial account balance for most countries in their sample. Our estimates indicate that a 1 percent increase in FA causes 0.59 percent decline in $\mathrm{BD}$. However other regressors don't have a significant effect on the budget balance in the long run. This result may be regarded as a bit surprising when the expected close relationship between the government budget balance and especially private sector balance taken into consideration.

The results of error correction estimates are reported in Table 4. We find that the FA and the lags of $\mathrm{CH}$ have negative and statistically significant impacts on BD in the short run. An increase in $\mathrm{FA}$ and $\mathrm{CH}$ leads to a decrease in $\mathrm{BD}$ in the short run. The negative coefficients on $\mathrm{CH}$ imply a procyclical behaviour, because 
the budget balance declines as a response to an increase in the household consumption. We should also note that the coefficient on error correction term is negative and significant, confirming the cointegrating relationship among our variables. It seems that about $46 \%$ of any disequilibrium eliminated in the short run.

Table 4. Error Correction Model

\begin{tabular}{|l|l|l|l|}
\hline \multicolumn{4}{|c|}{ ARDL $(1,0,0,1,4)$ (Dependent variable $=\Delta B D)$} \\
\hline Regressor & Coefficient & Standard error & t-ratio (prob) \\
\hline$\Delta$ PSB & -0.012633 & 0.042326 & $-.29846(0.767)$ \\
\hline$\Delta \mathrm{GE}$ & -0.023680 & 0.065668 & $-.36060(0.720)$ \\
\hline$\Delta \mathrm{FA}$ & -0.66422 & 0.049467 & $-13.4275(0.000)$ \\
\hline$\Delta \mathrm{CH}$ & -0.0013842 & 0.042003 & $-.032955(0.974)$ \\
\hline$\Delta \mathrm{CH}(-1)$ & -0.13155 & 0.055864 & $-2.3547(0.022)$ \\
\hline$\Delta \mathrm{CH}(-2)$ & -0.096881 & 0.048025 & $-2.0173(0.049)$ \\
\hline$\Delta \mathrm{CH}(-3)$ & -0.22706 & 0.041923 & $-5.4161(0.000)$ \\
\hline Constant & -0.019234 & 0.0056933 & $-3.3783(0.001)$ \\
\hline $\mathrm{ECT}(-1)$ & -0.46170 & 0.11516 & $-4.0094(0.000)$ \\
\hline
\end{tabular}

Following Granger et al. (2000), we also perform short run causality tests. Table 5 presents Granger-causality test results based on the error correction model. We find that FA and $\mathrm{CH}$ Granger cause BD while PSB and GE do not. Finally our regressors jointly Granger cause BD.

For diagnostic check, we carry out LM test and CUSUM test for the serial correlation and parameter stability, respectively. Our results suggest that there is no serial correlation and parameter instability at $5 \%$ significance level.

Table 5. Granger-Causality test results

\begin{tabular}{|l|l|}
\hline Direction of causality & Wald test statistic \\
\hline $\mathrm{PSB} \rightarrow \mathrm{BD}$ & 0.089080 \\
\hline $\mathrm{GE} \rightarrow \mathrm{BD}$ & 0.13003 \\
\hline $\mathrm{FA} \rightarrow \mathrm{BD}$ & $180.2977^{*}$ \\
\hline $\mathrm{CH} \rightarrow \mathrm{BD}$ & $32.5891^{*}$ \\
\hline Joint causality & $378.5760^{*}$ \\
\hline
\end{tabular}

Notes: ${ }^{*}$ shows significance at $1 \%$ level. 


\section{Conclusion}

In this paper we examine the effects of private sector balance, growth rate, financial account balance, household consumption expenditures on the government budget balance by using quarterly data for Turkey over the period 1998-2014. We employ ARDL approach to cointegration and also Granger causality tests.

Our visual examination suggests that there is a negative relation between the private sector balance and government budget balance during the period examined. The government budget deficit, thanks to many factors, has significantly declined since 2003. On the other hand the private sector balance has remarkably worsened around the same period. This means that the difference between the private saving and investment has increased. In Turkey there is a substantial decline in the private saving in recent years.

Our results indicate that a cointegrating relationship exists among our variables. However we find that financial account balance is the only variable which has a statistically significant effect on the government budget balance in the long run. Our estimates imply that an increase in the financial account balance leads to a decline in the budget balance. We conclude that both the financial account balance and the lags of household consumption expenditures have significant and negative impacts on the government budget balance in the short run. We should note that the private sector balance and growth rate don't have any significant effect on the government budget both in the long and short run. In other words, the government budget balance does not react to the changes in private sector balance and growth rate. We also find that the financial account balance and lags of household consumption expenditures Granger cause the government budget balance. On the other hand the private sector balance and growth rate do not Granger cause the government budget.

We would like to point out that for emerging economies, like Turkey, it would be good to have a high investment level. However, a growing or significant difference between the saving 
and investment levels may cause some important problems and bring some costs. Therefore, when the significant reduction in the private saving in recent years taken into consideration, Turkey should implement some pro-saving or saving friendly policies to reduce its high current account defictis, while maintaning fiscal discipline.

\section{REFERENCES}

Abdih Y., Lopez-Murphy P., Roitman A., and Sahay R. 2010. The cyclicality of fiscal policy in the Middle East and Central Asia: Is the current crisis different?. IMF Working Paper, WP/10/68.

Acaravcı, A., and Öztürk, İ. 2008. Twin deficits phenomenon: Empirical evidence from the ARDL bound test approach for Turkey. International Journal of Statistics \& Economics, 2(8), 57-64.

Akbaș, Y. E., Lebe, F., and Zeren, F. 2014. Testing the validity of the triplet deficit hypothesis for Turkey: Asymmetric causality analysis. Journal of Business and Economics, 7(14), 137-154.

Aksu, H., and Bașar, S. 2009. Türkiye için ikiz açıklar hipotezinin tahmini: Bir sınır testi yaklașımı. Ankara Üniversitesi SBF Dergisi, 64(4), 1-14.

Alesina, A., Campante, F., and Tabellini, G. 2008. Why is fiscal policy often procyclical?. Journal of the European Economic Association, 6(5), 10061036.

Aristovnik, A., and Djuri冈, S. 2010. Twin deficits and the Feldstein-Horioka puzzle: A comparison of the EU member states and candidate countries. Munich Personal RePEc Archive, No: 24149.

Barro, R. 1974. Are government bonds net wealth?. Journal of Political Economy, University of Chicago Press, 82(6), 1095-1117.

Barro, R. 1989. The Ricardian approach to budget deficits. Journal of Economic Perspectives, American Economic Association, 3(2), 37-54.

Ciumas, C., Vaidean, V., and Karsai, Z. 2012. Implications of private sector behavior on public finance sector. Procedia Economics and Finance, 3, 152-157.

Çatık, A. N., Gök, B., and Akseki, U. 2015. A nonlinear investigation of the twin deficits hypothesis over the business cycle: Evidence from Turkey. Economic Systems, 39(1), 181-196.

Engle, R. F. and Granger, C. W. J. 1987. Co-integration and error correction: Representation, estimation and testing. Econometrica, 55(2), 251-276. 
Erden, L., and Çağatay, O. 2011. Türkiye'de cari ișlemler ve sermaye hesapları arasındaki ilișki. H.Ü. iktisadi ve İdari Bilimler Fakültesi Dergisi, 29(2), 49-67.

Erdoğan, S., and Yıldırım, D. 2014. The relationship between the budget deficit and current account deficit in Turkey. Emerging Markets Journal, 3(3), 81-86.

Fry, M., Claessens, S., Burridge, P., and Blanchet, M. 1995. Foreign direct investment, other capital flows, and current account deficits, what causes what?. The World Bank International Economics Department, Debt and International Finance Division, Policy Research Working Paper, No: 1527.

Gali, J., and Perotti R. 2003. Fiscal policy and monetary integration in Europe. NBER Working Paper Series, No: 9773.

Granger, C.W.J., Huang, B. N., and Yang, C. W. 2000. A Bivariate causality between stock prices and exchange rates: Evidence from recent asian flu. The Quarterly Review of Economics and Finance. 40, 337-354.

Gursoy, B. and Ceylan, C. 2011 . The twin deficits phenomenon: Evidence from Turkey. China-USA Business Review, 10(8), 636-642.

Hakkio, C. 1995. The U.S. current account: The other deficit. Federal Reserve: Bank of Kansas City Economic Review, 3, 11-24.

Hatemi, A., and Shukur, G. 2002. Multivariate-based causality tests of twin deficits in the US. Journal of Applied Statistics, 29(6), 817-824.

Kaminsky, G., Reinhart, C., and Végh, C. 2004. When it rains, it pours: Procyclical capital flows and macroeconomic policies. NBER Working Paper Series, No: 10780.

Khalid, A., and Guan, T. 1999. Causality tests of budget and current account deficits: Cross-country comparisons. Empirical Economics, 24, 389-402.

Kılavuz, E., and Dumrul Y. 2012. The validity of twin deficits hypothesis: Theory and practice. The Journal of Faculty of Economics and Administrative Sciences of Atatürk University, 26(3-4), 239-58.

Kıran, B. 2011 . On the twin deficits hypothesis: Evidence from Turkey. Applied Econometrics and International Development, 11 (1), 59-66.

Kumhof, M., and Laxton, D. 2013. Fiscal deficits and current account deficits. Journal of Economic Dynamics \& Control, 37, 2062-2082.

Kuștepeli, Y. R. 2001. An empirical investigation of the Feldstein chain for Turkey. Dokuz Eylül Üniversitesi İșletme Fakültesi Dergisi, 2(1). 99-108.

Lane, P. 2003. The cyclical behaviour of fiscal policy: Evidence from the OECD. Journal of Public Economics, 87, 2661-2675. 
Marinheiro, C. 2008. Ricardian equivalence, twin deficits, and the FeldsteinHorioka puzzle in Egypt. Journal of Policy Modeling, 30, 1041-1056.

Merza, E., Alawin, M., and Bashayreh, A. 2012. The relationship between current account and government budget balance: The case of Kuwait. International Journal of Humanities and Social Science, 2(7), 168-177.

Murthy, V., and Phillips, J. 1996. The relationship between budget deficits and capital inflows: Further econometric evidence. The Quarterly Review of Economics and Finance, 36(4), 485-494.

Pesaran, M. H., Shin Y., and Smith R. J. 2001. Bounds testing approaches to the analysis of level relationships. Journal of Applied Econometrics, 16(3), 289-326.

Tang, T. C. 2014. Fiscal deficit, trade deficit, and financial account deficit: Triple deficits hypothesis with the U.S. experience. Monash University Department of Economics, Discussion Paper, 06/14.

Turan, T., and Telatar, E. 2013a. Türkiye için sabit ve zaman değișken katsayılı ampirik mali kural tahminleri. H.Ü. Iktisadi ve Idari Bilimler Fakültesi Dergisi, 31 (1), 225-248.

Turan, T. 2013b. Türkiye'de maliye politikası konjonktür yanlısı mı? Uludağ Üniversitesi Iktisadi ve İdari Bilimler Fakültesi Dergisi, 32(2), 123-140.

Turan, T. 2013c. Cyclicality of fiscal policy in Turkey. The Empirical Economics Letters, 12 (11), 1219-1228.

Turan, T. 2014. Hükümet harcamalarında konjonktürel mandal etkisi: Türkiye örneği" Çukurova Üniversitesi Sosyal Bilimler Enstitüsü Dergisi, 23(2), 177 188.

Turan, T. 2015a. Türkiye'de bütçe dengesi ve finans hesabı dengesi arasında bir ilișki var mı? Yönetim ve Ekonomi Dergisi, forthcoming.

Turan, T. 2015b. The causal relationship between current account and financial account balance in selected CEE countries, Economicky Casopis, forthcoming.

Salvatore, D. 2006. Twin deficits in the G-7 countries and global structural imbalances. Journal of Policy Modeling, 28, 701-712.

Ümit, A., and Yıldırım, K. 2008. Twin deficits hypothesis. İktisat İsletme ve Finans, 23(267), 116-132.

Wong, C. H., and Carranza, L. 1999. Policy responses to external imbalances in emerging market economies: Further empirical results. IMF Staff Papers, 46(2), 225-237.

Xie, Z., and Chen, S. 2014. Untangling the causal relationship between government budget and current account deficits in OECD countries: Evidence 
from bootstrap panel Granger causality. International Review of Economics and Finance, 31, 95-104.

Varol lyidoğan, P. 2013. The twin deficits phenomenon in Turkey: An empirical investigation. Journal of Business, Economics \& Finance, 2(3), 36-42.

Yan, H.-D. 2005. Causal relationship between the current account and financial account. International Advances in Economic Research, 11 (2), 149-162.

Zivot, E. and Andrews, D.K. 1992. Further evidence on the Great crash, the oil-price shock, and unit-root hypothesis. Journal of Business \& Economic Statistics, 10(3), 251-270. 